\title{
Partition of Indian Subcontinent: A Thought-Provoking Outcome of the Prevailing "Anachronistic" Approach to Religion instead of "Modern"
}

\section{Ramani Naik}

Ph. D. Scholar

P.G. Dept. of English

Sambalpur University

Jyoti Vihar, Burla, Odisha, India

naikramani@gmail.com

\begin{abstract}
Understanding of the holocaust event, 'Partition of Indian Subcontinent'(1947) still appears a problematic chapter to deal with even after more than seven decades of the holocaust event not only for millions of Indians and Pakistanis but for many in abroad too. The momentous event still continues to tantalize many historians, writers, researchers and scholars at present day context even. Reading history is not enough to understand this event of great vastness. Literary representation of Partition also plays a significant role in this regard. The cataclysmic event has been documented in a wide range of literary genres -fictions, non-fictions, poetry, memoirs, oral history etc., published in multiple languages in many countries. All the writers try to capture the most harrowing scenes of the turbulent period of history as per their immensity of experiences and meticulous observation. Besides many reasons responsible for the Partition, the underlying 'anachronistic' approach to 'religion' is noticed as the most prominent one in resulting the thought-provoking disaster of 1947. The present paper seeks to explore 'the' least attended
\end{abstract}


aspect but 'the' most important reason of the holocaust i.e. the prevailing anachronistic approach to "religion" instead of "modern" with special reference to Brent Nonbri's idea of "modern concept" of an "ancient( traditional)" notion of "religion."

Keywords: Anachronistic Approach to Religion; Indian subcontinent; Modern; Partition; Religion;

\section{Introduction}

The vastness of the cataclysmic Partition of Indian Subcontinent (1947) and its legacies still need an expanded framework for its assessment. There were many remarkable situations (social, political and historical), underlying concepts and reasons responsible for the catastrophe. Those contexts include : The underlying 'anachronistic' perspective to 'religion' instead of 'modern' ; Growing religious hatred between two major religious groups (Hindu-Muslim on the basis of their historic and cultural roots of discord) ; Influence of foreign invasion on the subcontinent; the rise of narrative for two different types of religious nationalism (Hindu nationalism and Muslim Nationalism) which turned into 'communal' form of nationalism ; Insertion religion into politics; Gandhi's Hindu religious biasness as a strategy of freedom struggle ; Burden of WWI and WWII on Indians as well as on British ; suddenness of decision for Partition ; Divide and Rule policy of British ; Late announcement of boundary demarcation line( Radcliffe line) ; Lack of development and spread of massive secular thought among the frontline political leaders (except Jawaharlal Nehru) as well as among the masses ; Lack of implementation of the great, ideal concept "Unity in Diversity" ( the state of togetherness in spite of presence of immense diversities) in reality etc. With the existence and developments of these events and concepts, the cataclysmic Partition was made inevitable. 
The magnitude of the event has far-reaching consequences in constructing memory for generations that gives rise to form a new literary paradigm called Partition Literature and an archive in the name of 1947 Partition Archive( founded by Guneeta Singh Bhalla), a nonprofitable organization that is working into digging various details of Partition of the Indian subcontinent through recording and compiling of oral stories of the victims and witnesses of Partition.

In fact, Partition of Indian Subcontinent was not a simple geographical partition literally. Millions of human lives, age long languages, cultures, valuable properties, were partitioned forcefully in a hasty process which still has its legacies in Indian as well as Pakistani way of life(socio-political, economical and cultural). The major untoward consequences of the decision for Partition include - massive exodus, loot, rape, murder symbolizes Partition. Hence, the whole event is considered as a great holocaust as humanity was partitioned along with land. Mahatma Gandhi appropriately defines this forceful Partition as the "vivisection". In the article entitled, "Generations of memory: Remembering Partition in India/Pakistan and Israel/Palestine", Jonathan D. Greenberg rightly acknowledges Gandhi's metaphorical usage of the term Partition, "Tragically for the people of the subcontinent, Gandhi's version of the body politic metaphor was far closer to the truth"(Greenberg,92). Ian Talbot and Gurharpal Singh viewed Jinnah's version of Partition as “a surgical operation”. Joya Chatterji notes Lord Mountbatten's response to Jinnah's idea of a surgical partition , "An anesthetic is required before the operation"( Chatterji, 194). Referring to Stanley Wolpert's analysis on Neheru's point of view on Partition, Jonathan D. Greenberg writes, "Even Jawaharlal Nehru came to believe that "[by] cutting of the head we will get rid of the headache" (Greenberg, 92). However, amidst many theses of many frontline political leaders in Pre-partitioned India, finally Partition was come into being. 
However, the religious hostilities were not solved with the great vivisection. The spatial aspects of the holocaust and its traumatic implications in mindscape are getting reflected in much dynamic manner even at present context which seems far-reaching and edgeless.

Although it is true that by the time of Partition, communal tension had reached high through the major riots in 1940s but the seeds of communal poison were sown much before the decision of Partition. On the one hand many Hindu political leaders like Mahatma Gandhi, Lala Lajpat Ray, Savarkar Patel and some Hindu fundamentalists organizations (Hindu Maha Sabha, RSS etc. ) and their very strategies of works to attract people politically and somehow on the basis of their religious majority ; on the other, many Muslim political leaders like Shaukat Ali, Mohammad Ali Jauhar, Mahammad Ali Jinnah etc., and some Muslim fundamentalists organization(All India Muslim League, Khilafat committee etc.) and their respective strategies to attract mostly Minorities(Muslims) played a significant role in injecting "religion" into politics. Gail Minault critically views the Ali brothers prepared the ground to blend religion with politics, getting influenced by Gandhi's speech, "Politics cannot be divorced from religion" (Minault, 56). Thus, Ali brothers got an ammunition in the same line to attract Muslim masses like Gandhi who could attract Hindu as well as Muslim masses using his Hindu religious bent of mind as a major tool of organizing masses. Analyzing Gandhi, Dilip Hero aptly states in The Longest August: The Unflinching rivalry between India and Pakistan, "Gandhi drew much of his nationalist inspiration from the traditional myths, beliefs and symbols of Hinduism"( Hero,31). Moreover, quoting his own work, The Timeline History of India, Hero notes in the chapter "Gandhi's Original Sin: Injecting Religion into Politics" of the book The Longest August : The Unflinching Rivalry between India and Pakistan, Gandhi once explained, 
"My bent is not political but religious. And I take part in politics because I feel there is no department of life that can be divorced from religion"(Hero, 31).

However, Gandhi's religious bent of mind was not communal as it was in the part of other leaders like Savarkar, Patel (the ardent believers of Hindutva ideology). He was a believer of Hinduism but not of Hindutva for which he had to pay with his life by the assassin, Nathuram Godse( a strong supporter of Hindutva ideology) because he was targeted to be killed many times by Godse before the final attempt. Although Gandhi was not in favour of Partition of the subcontinent, still it was made inevitable as per the demand of the then prevailing socio- political and communal situation in the subcontinent. Instead of celebrating the much awaited historical moment of Independence in Delhi like other leaders, Gandhi made himself engaged in serving riot affected victims in Calcutta. Shibdas Ghosh compares Gandhi with an affectionate, superstitious mother who was indulged in rigorous fasting, worshipping god to cure her sick child 'colonial India'. According to Ghosh, Gandhi's ideology was a fusion of religion, Indian traditionalism, the bourgeoisie humanist thoughts and ideas that couldn't help him to understand the flow of "religious nationalism" trend in pre-partitioned India. As a result, without a secular root, Indian nationalism and democracy seems fragile in many ways.

In spite of many causes responsible for Partition, "the religious animosity" is considered as the most prominent one. By the time, when the subcontinent was partitioned, the very concept of "the religious hatred" had already been transformed into "communal hatred" through frequent occurrence of communal violence. Referring to communal violence as a strong legacy of Partition, Asghar Ali Engineer aptly notes in the article, "Communal violence in Maharastra", " ... partition, as expected couldn't resolve the problem ... Communal violence ... can never be explained in terms of [religion] alone, though some people insist on [religion] being the most 
important factor. If religion alone were to explain it, one will be hard put to explain near absence of communal violence throughout the medieval period when [traditional religion] had much greater role in people's lives"(Engineer, 148). Quoting Abid Hussain's idea on the prevailing communal atmosphere in pre-partitioned India, Anup Chand Kapur writes, "We should remember that in the period of political transition, the struggle for political transition, the struggle for political, economic, and cultural domination among followers of various religions had become a powerful separating force ...”(Kapur,15). However, like Hussain, Ashghar Ali Engineer also emphatically notes, in the article, Genesis of Communal Violence", " a shift in the economic and political situation with the introduction of the British Raj led not only to the strengthening of communal prejudices but also to periodical outbursts of communal violence which assumed a certain pattern over a period of time and culminated in the partition of the country" (Engineer,189). But it is noteworthy here to mention that British was not simply an alien force, moreover it was the third party that tried its best to instill its strategy of "divide and rule" for a lasting period using "religion" as the most fitted weapon. With the colonization of British, Christianity was also involved in the long term religious hostility between Hindus and Muslims and strengthened it more for its own benefit. Thus, the dispute was not among the Hindus and Muslims only but amongst the three communities - Hindus, Muslims and Christianity, while the earlier two were the subjects and the later one was the ruler.

2. Divide and Rule policy:

The first colony of the British empire that was partitioned along religious line was Ireland and second was Indian subcontinent. Analyzing the very common feature of 'divide and rule' in The Longest August: The Unflinching Rivalry between India and Pakistan, Dilip Hero, says, "What was common between the two partitions was [religious affiliation]. In the case of Ireland 
, it was different sects within Christianity, whereas in united but colonized India it was a clash between polytheistic Hinduism and monotheistic Islam”( Hero,xi). In a heterogeneous society, inter-group conflicts are inescapable part of public life which is difficult to avoid literally. So, far as Partition of India was concerned on the basis of religion it was happened in a context when approach to religion was not "modern" but still "anachronistic". This "anachronistic(traditional) treatment" of "religion" still exists in modern society which is a major challenge today to overcome. In fact the issue exists worldwide ( in underdeveloped, developing or even for developed nations). At this juncture, a critical analysis on Nongbri's idea of 'modern' notion of religion seems more helpful.

3. Nongbri's version of 'ancient' concept of 'religion'

In order to have some sort of clear-cut idea on 'religion' from modern point of view Brent Nongbri's concise account of modern notion of 'religion' is noteworthy to refer to in the background context of Partition of Indian subcontinent. Nongbri tends to guide through his treatise, Before Religion: A History of a Modern Concept, to rethink the concept 'religion' in brief in modern context. According to his minute observation, even at present context, very often most of the people in general deal with it (religion) anachronistically but not from the modern point of view. The idea of "religion" is still being propagated with nothing "new" in modern context. It still exists as a concept "preoccupied with" many age old rituals, beliefs and doctrines which are treated as "sacred" and "good" in so-called way and thus "necessary" to follow as it was used in one way or the other in ancient and mediaeval society. But so far as the enlightening ideas of modern society is concerned, no more the ancient concept of religion is found helpful rather harmful. Because the traditional concept of religion creates many hindrances, confusions and helps only in blockading the exploration of science, scientific ideas, 
scientific temperament, humane human attitudes etc., in many ways in global context . If these (religions) are considered somehow useful by some people ( "a majority" or "minority" group of people as per their respective beliefs ) then it is to be understood that such considerations are only trying to serve 'some' sorts of purpose in private as well as public sphere of lives "more" (on the basis of socio-political, cultural and economical context) but serving "less" to justify its "traditional meaning" in general what it is assumed to be (believing any religion means believing in an interior spiritual journey for the so-called salvation concept of soul etc.).

Karen Armstrong's (the former nun and best-selling author) views, "The spiritual quest is an interior journey; it is psychic rather than political drama. It is preoccupied with liturgy, doctrine, contemplative disciplines and an exploration of the heart, not with clash of current events"(Armstrong, ix). Here it seems, somehow Armstrong puts her opinion in the line of Locke, that the position of 'religion' is confined to 'the' private context (by using two specific words 'psychic' and 'interior journey') and should not be applied publicly and politically.

In ancient period, the discussion on sacrality and gods were very much in the public domain. They referred to the concept of religion in their hierarchical protocols of all sorts. As per Nongbri's study: For example- In Greek, the people frequently uses the word "eusebeia" to perceive proper attitude towards Gods and parents and "asebeia" for holding wrong attitude. Referring to Plato's Republic, Nongbri writes, "Plato emphasizes the rewards for those who display[eusebeia] and punishments due to those who display [asebeia] to gods and parents"(Nonbri,4). Moreover, referring to John. E. Stambaugh's writing on the function of Roman temple, he writes during that time Roman temples were used as sacred sites where a wide varieties of activities (for example : festivals or sacrifices dedicated to gods, banks, libraries, meeting places for governmental bodies, markets, repositories of legal records, banks, 
museums etc.) could have been performed for which the people in modern context would not describe those temples as " religious" places. Because in today's context, the mostly used definition of "religious place" refers to "place of worship" or the site to perform some rituals but not other activities. So far as the modern notion of religion is concerned, Nogbri emphatically puts a key question to explore "how and when people came to conceptualize the world divided between [religious] and [secular] in modern sense and to think the religious realm as being divided into distinct religions, the so-called World Religions”( Nongbri,5).

4. Nongbri's modern notion of ancient concept of "religion"

In order to define the 'modern' concept of religion, Talal Asad views, "I would urge that [religion] is a modern concept not because it is reified but because it has been linked to Siamese twin [secularism]'( Asad, 205-22). Supporting Asad's point of view, Nongbri emphatically says, "It is this simultaneous birth of 'religion' and 'secularism' that merits attention"( Nongbri,4). He claims that what modern people perceive the domain of religion today was absent in the ancient world. Because the modern dichotomy of "being religious" and "not being religious" was not of concern of the ancient world. He clarifies, "The very idea of [being religious] requires a companion notion of what it would mean to be [not religious] and this dichotomy was not part of the ancient world" (Nongbri,4). Thus, he critically points out, "What is modern about the ideas of [religions] and [being religious] is [the isolation] and naming of some things as [religious] and others as [not religious] (Nongbri,4)". In the chapter, “Conclusion: After Religion?" he discusses the origin of "modern" notion of "ancient" concept of "religion" in an informed way. Focusing the origin of "modern" concept of religion, he says, "It was born out of a mix dispute Christian disputes about truth, European colonial exploits, and the formation of nation-states"(Nongbri, 154). Moreover, he aptly says the democratization of the modern idea of "religion" started when 
it was applied in cross-cultural context. According to him, when the intra- Christian sectarian disputes ( the idea of which form of Christianity was true: Catholic or Protestant) coincided with European exploration of the world, they discovered the "new" people ( in Africa, America etc.,) and their different worship practices. Thus, Nongbri appropriately says, these "new" peoples became the "ammunition" for the world of Christian disunity which was found as the very 'basis' to construct the framework of World Religions. The advocate of constructing the phenomena of "modern idea of religion" in $16^{\text {th }}$ century was John Locke who recommended to treat religion 'privately' and 'apolitically' for the betterment of growing nation-states with which the modern notion of "religion" ( the distinction between "the religious" and "the secular") came into existence.

The trajectory from ancient to modern records many kinds of developments of different societies time to time. What is most important to note here is that in spite of much progress of human lives by the modern era, there still found some kind of influences of mediaeval pagan beliefs and practices in modern society all over the world. The different taboo subjects - religion, ethnicities , culture, language etc., still has its dominance in shaping the "psychology" as well as "social behavior" as per the age long underlying ancient beliefs. So far as the theory of evolution and the idea of secularism is concerned, it is observed not yet the people( in general in the present modern society) have achieved the modernized status in their outlook, socio-cultural behavior, economic and political development etc., in global context.

However, so far as the concerns of religion is meant in general in traditional sense, people believe "religion" as a kind of inner feeling or personal belief which is ideally remote from secular affairs. Thus, in this scenario, independent World Religions are considered as different platforms in order to know about the genesis of world, creation of life, how to obtain 
salvation, what's the best way to realize the concept of "almighty", "supernatural entity" or "god" etc.

5. "Defining religion" is a peculiar job

The very process of 'defining religion' seems a peculiar job to discuss but can't be ignored as it has still a strong dominance on the traditional belief system of people. As Nongbri suggests ideally, it is the need of the hour to have a clear-cut idea on 'modern' concept of religion. Eric J. Sharpe, the historian of comparative religion opines, "To define religion is, then far less important than to possess the ability to recognize it when we come across it" (Sharpe, 4648). Sharing his experience as a Prof. of History of Religions, Brent Nongbri writes, "When I ask my students to define religion, they generally respond with a wide range of conflicting definitions, but they usually can agree on [what counts] as religion and [what does not]" (Nongbri,15). Regarding the defining process of "definition" of religion, Jonathan Z. Smith claims, "the very process" can take an entire book or several books to catalogue the numerous attempts at defining religion. Nongbri says that James H. Leuba (Prof. of Psychology) notes fifty definitions of religion in the appendix of his work A Psychological Study of Religion: Its Origin, Function, and Future (1912). Responding to Leuba's cataloging of definitions on religion, Jonathan Z. Smith( an American historian of religions) views, “. . . it can be defined, with greater or lesser success, more than fifty ways"( Smith,179-196). However, analyzing Smith's and Leuba's points of view, Nongbri critically observes, "the industry of proposing new, [better] definitions of religion shows no signs of flagging, despite the decreasing sense that any universal definition will ever be accepted"( Nongbri,16).

Nongbri intelligibly and justifiably rejects the efforts of producing "better definitions" or "more cross-culturally valid definitions." According to him "the" very process as well as "the" 
very purpose is misguided. At this juncture, it is noteworthy to refer to Benson Saler's idea of producing better definition of religion. Advising his associate anthropologists, Saler says what is important is not try to produce a "better" or "inclusive" definition of religion. According to him, religion has its "traditional meaning for us and for the audience for which we write, and by so widening or otherwise altering what it includes, it may well cease to have much utility as a research and literary tool" (Saler, 157). Nongbri notes as an academic discipline, the study of religion still assumes "religion is simply a fact of human life and always has been." Thus, a key question arises, "How should the study of religion move forward?" (Nongbri,154). Hence, he suggests to study religion in a more informed way and putting two crucial questions in this regard to focus on.

1. Who is doing the defining and why?

2. What is at stake for those who think it is important to adhere to this or that particular definition of religion?

In the article, "God Save This Honourable Court: Religion and Civic Discourse", Jonathan Z Smith discusses “. . .government entities in the United States determine what does and does not get to count as religion through an examination of Supreme Court cases." (Smith, 375-90). In this regard, Nongbri critically views, "This kind of approach has more potential for generating useful insights. What sorts of interests are involved in such decisions of defining religion?"( Nongbri,155). In many countries this problem of "direct involvement" of government machinery in the affairs of religion still exists. Amongst them, the so-called largest democracy and the so-called secular 'India' is 'one'.

6. Direct "involvement" of Government in the affairs of religion in the so-called secular India 
With particular reference to the recent verdict on "Ram Janmabhoomi(birth place of Ram)- Babri mosque dispute" in 2019 , it is observed that like U.S. in India also it is "the same" Supreme Court that dramatically acts as the "Supreme Tool" not only in "defining" what is religion but also "which religion is more important and which is less" as per the dominating "majority vs. minority" narrative. The very verdict puts a question mark on the secular character of Indian constitution. Despite knowing the fact of the demolition of Babri Masjid (A Mosque built by Mughal emperor Babur in $16^{\text {th }}$ century) in Uttar Pradesh, India on 6th Dec,1992 by a large group of the activists of Viswa Hindu Parishad and its allied organizations, " the way" the Supreme Court of India releases its verdict ( giving the complete custody of the disputed land of 2.77 acres to Hindus and another "unasked" five acres of land to Muslims as an alternative other than the disputed land) in order to dissolve the dispute still demands an inquisitive analysis in understanding the very 'basis' of the judgment. Moreover, the acquittal of all thirty two accused (of demolition case) including BJP veterans L.K. Advani(former deputy PM), Murli Manohar Joshi, Uma Bharti, Kalyan Singh etc. by a special CBI court in Lucknow marks a milestone in questioning the 'justness' of Indian judiciary so far as the verdict is concerned under the double-engine leadership of BJP govt. both in Uttar Pradesh( Yogi Adityanath govt.) and at the Centre ( Narendra Modi govt. ). TJS George aptly records the verdict in an article with a catchy title "28 years after Babri masjid demolished yet again" in The New Indian Express. Moreover, the seriousness of Narendra Modi, (the Prime Minister's role) in the ground breaking ceremony for the construction of Ram temple in Ayodhya, using $22.6 \mathrm{~kg}$ (worth 15 lakhs) of silver brick draws significant attention in this regard. Thus, the whole process from the 'demolition' of Babri mosque to the 'construction' of Ram temple speaks a lot about " the defining” responses of Indian judiciary to 'religion'. 
About the status of religion in post-partitioned India, Gurpreet Mahajan critiques:

The Indian Constitution dealt with the issue of [religion] by endorsing the principle of non-establishment of religion but without advocating the separation of religion from politics ... This meant that the state was to have no religion of its own, but religion was not viewed as a personal or private matter : it was placed [squarely] in the public domain and the state was expected to be involved in a variety of ways with religion (Mahajan,301-302).

So far as the recent "Ram Mandir-Babri mosque" verdict is concerned, Gurpreet Mahajan's analysis seems very much appropriate in this regard.

According to Nongbri, the "activity" of defining the religion and the "act" of saying "some things" or "Some people" are religious and others are not, lead to giving up "the essentialist project" of finding "the" definition of religion. In his words, "Such a reorientation in the study of religion would also allow for a more playful approach to second-order redescriptive usage of religion"( Nongbri, 155). Thus, he emphasizes on, to treat 'something' as religion in 'non-essentialist' ways for the purpose of 'analysis' that would shift the mode of discourse. He suggests intelligibly with the shifting of mode of discourse, "We would no longer ask the question, 'Is phenomenon $\mathrm{X}$ is a religion?' Rather we would ask something like 'Can we see anything new and interesting about phenomenon $\mathrm{X}$ by considering it, for the purpose of study, as a religion?" (Nongbri, 155). With the attempt of shifting mode of discourse, Nongbri opens up the concept of religion to be responded in a more informed way.

\section{Critiquing 'Religion'}

In fact it seems unworthy to discuss "religion" merely as "re-descriptive" concept in order to have some kind of idea on creation and destruction of universe, attaining salvation etc. It 
seems unhelpful and harmful too to ignore the scientific theory of evolution( by Charles Darwin) and implementation of laws of science (that creates a genuine scientific temperament and developing scientific, humanitarian approach to different aspects of life and society).

Due to "squarely" assigned status of religion in the so-called secular country like India, its claim of "secular" character contradicts itself. At this juncture, it seems more appropriate to consider India either as a pseudo-secular nation or as a "multi-theocratic state" (according to Shibdas Ghosh- A Scientific Approach to Our Educational-Cultural Problems) but not a secular state. So far as Indian secularism is concerned only for the sake of name, it invites many provocative ideas and incidents(especially communal violence) that are unexpected and infamous by nature.

8. The Present Relevance of Study of "religion"

Including Nongbri, many scholars like Beverly Milton Edward, Salman Rushdie, Gurperet Mahajan, Khuswant Singh, Paul R. Brass etc. agree with a basic concept that religion, ethnicity, tribe and clan etc., are found as the foundation of ancient hatreds which impedes the progress of modern secular ideals. Analysing the rising conflicts and violence in this regard, Beverely Milton Edwards notes insightfully, “. . . the politics of ancient blood and nation, religion and ethnicity ... are a challenging and uncomfortable reminder that perhaps all is not well with the modern age. Perhaps the liberalization or abandonment of old taboos, norms and values and rites and rituals does not necessarily bring us to a better place where violence is reduced or increasingly absent"( Edwards, 20-21). However, liberalization of old taboos is not a solution to stop violence. At this juncture, it is necessary to discuss the pros and cons of these old taboo ideas from a modern, secular, scientific and humanitarian perspective with special 
reference to Marx's recommendation for "abolition" of religion and Nongbri's recommendation to study religion "in a more informed way" ( Nongbri, 154).

Although it seems difficult to abolish the influence of religion completely from social life but not seems impossible as well. The more influential and interesting part to study and discuss religion would be to focus it as a research area with a sound questionnaire in order to discuss some key questions as such: Can ancient notion of religion be abolished from social life? What can be the "procedure" of abolition of religion? What can be the result if all the people in the whole world become atheists? Can the society progress or regress with the abolition of "religion"? If there occurs some progress, then what would be the nature of progress of human life socio-politically, culturally, economically and philosophically? If there occurs some regresses, then what would be its nature? What would be the benefits for the individuals as well as for the whole human society with the abolition of traditional concept of religion? Isn't it the need of the hour to prepare a valid ground for each individual in human society in order to inculcate secular, scientific and humanitarian approach to life and society for common good. Perhaps all such questions may provoke some valuable assessment on the idea of "religion" in a more informed way.

Critiquing Marx's comparison of religion with opium, Beverely Milton Edwards states, "religion is not so much an opiate of the masses but is harnessed by the state elite into the fabric of the state - to varying degrees -as a means of force and order"(Edwards,29). According to Nongbri's insightful claim, what seems more authoritative in the problematic study of religion is "to simply view it as a modern subject" focusing the "particular" time of John Locke's scholarly recommendation for the treatment of religion when it was truly reorganized as a modern concept. There is found a great challenge before modern man not only to be 
modernized but also to be secularized both in words and in actions and social behavior for public good.

9. Usage of the term 'anachronism'

According to Nongbri, he uses the term "anachronism" for the study of ancient texts being influenced by Stephen D. Moore's idea of anachronism ( from his book God's Gym : Divine Male Bodies of The Bible). With the creative usage of the term by Nongbri in Before Religion :A History of a Modern Concept, he raises a crucial issue regarding the unwise exercise of application of "religion" in general. According to him, "The problem with using [religion] to talk about the ancient world is not anachronism. All of our concepts are modern and hence anachronistic when applied to the ancient world. The problem is that we so often suffer from a lack of awareness that we are being anachronistic. Informed and strategic deployment of anachronism, on the other hand, can have unexpected and thought-provoking results" (Nongbri,158). With this particular analysis, Nongbri guides to instill a "modern idea" rejecting the ancient notion of religion. He aptly focuses on the central issue that due to "informed and strategic deployment" of anachronistic ideas (old taboo ideas), it would have only one result i.e. to bring unexpected, unhappy, thought-provoking results. Because as the modern man lives within the circle of many modern ideas (cosmopolitanism, secularism etc. ) in a technologically advanced world as well, hence, while dealing with religion, it would be disadvantageous for him to confine his "mindscape and social space" in anachronistic (traditional) sense instead of modern . Nongbri knowledgeably makes it clear, "religion as an explicitly second-order or redescriptive concept has a place in the study of antiquity. That leaves us with the final question of what to do about our descriptive account of the ancient world" (Nongbri, 158). In fact, the study of 'religion' can be explored as a research field in a more productive way when it will be 
considered as a special discipline in order to study the history of ancient world and the role of religion in ancient society.

10. Conclusion:

'Wars' amongst different religions, ethnicities, cultures have not yet been ended. It is still being manifested in many societies, countries in the name of "civil war", "ethnic war" and "intra-religion wars", "inter-religion wars" etc. In Asian countries like India and Pakistan since the time of Partition, the legacy of religious violence still persists in communal form even after more than seven decades of the cataclysmic event of 1947. The tumultuous Partition still appears as a curious topic in public arena. Myriad attempts still are being made time to time to fill in the gap to understand the various circumstances why the infamous Partition took place.

However, if it is not considered that the horrendous event took place in the context of the "underlying anachronistic" approach to "religion," (that could have been avoided with a sensible and intelligible modern outlook to religion) then the gap would remain seemingly unbridgeable. From Nongbri's point of view, it can be emphatically concluded that the thought-provoking Partition of the Subcontinent happened due to "an underlying anachronistic approach to religion" in the modern period i.e. in 1947. Hence, if this valid ground is not taken into account as the most "noticeable ignorance" of the public as well as of the political leaders then all the myriads of attempts on the assessment of the great holocaust would go in vain.

Many thought-provoking events have occurred unexpectedly in global context due to "the" anachronistic approach to religion in modern era which can't be ignored. Including Partition ,the long term Ram temple-Babri Mosque dispute, and finally the dramatic narrative of 'demolition' of Babri mosque in 1992 and 'construction' of Ram temple at the demolished sight in 2020 etc., are fitting example of the reflection of the prevailing religious hostilities 
between Hindus and Muslims in India. The hostilities are not found merely religious but competitively communal as well.

The West and the Middle East are not exceptional in this regard. The cataclysmic events like "9/11 in USA," the recent "11 -day Palestinian- Israeli violence" in May, 2021, the ongoing military offensive by Taliban and allied groups since 1990s till date (the recent escalation of Taliban offensive in Afghanistan in August,2021) etc., are the most striking examples of some high degree of thought-provoking outcomes that happened in recent past in global context due to manipulation of "religion" in an inappropriate and 'atavistic' way instead of 'modern'. No peace talks and no reconciliation seems possible to escape from the attack of all kind of taboo subjects- religion, ethnicity, language, culture etc unless it is handled from "purely" modern scientific, humanitarian perspective exercising all the ideas knowledgeably and sensibly.

However, if some sorts of purposeful efforts are not being made seriously for the eradication of the very "basis" of religious hostilities as well as communal hatred then this "religious virus" may mutate its feature towards pandemic nature to perform its action in much more vigorous and violent way impeding "the" very process of progress of modern human society up to the mark and as a result, the modern society will lag behind more in achieving the great ideals - cosmopolitan democracy, secularism, socialism, humanism etc., in true sense. The modern man needs to be more socialized, democratized, secularized and above all humanized. The earlier is the diagnosis, the better is the treatment. 


\section{REFERENCES:}

Armstrong, K. Islam: A Short History. Phoenix. 2001, p. ix.

Asad, Talal. "Reading a modern Classic: W.C Smith's The Meaning and End of Religion." History of Religions. 40.3 (2001): pp.205-22 .

Bloch, Maurice. "Why religion is nothing special but is central."Philosophical transactions of The Royal Society B: biological sciences, 2008. 363(1499), 2055-2061.

Chatterji, Joya. "The making of a borderline: the Radcliffe award for Bengal." (1999): 168-202.

Engineer, Asghar Ali. "Genesis of communal violence." Economic and Political Weekly (1992): 189-190.

---."Communal Violence in Maharashtra." Economic and Political Weekly (1997): 148-149.

George, T J S. “28 Years after, Babri masjid demolished yet again.” The New Indian Express. $04^{\text {th }}$ Oct., 2020 .

Ghosh, Shibdas. "Cultural Movements in India and Our Task." Selected Works. Vol.II. Central Committee, Socialist Unity Centre of India,1992.

---. "A Scientific Approach to Our Educational -Cultural Problems." Marxist Internet Archive: Shibdas Ghosh. $4^{\text {th }}$ Feb. 1968. Accessed: 12 ${ }^{\text {th }}$ Aug., 2021., http://www.marxists.org Greenberg, Jonathan D. "Generations of memory: remembering partition in India/Pakistan and Israel/Palestine." Comparative Studies of South Asia, Africa and the Middle East 25.1 (2005): 89-110.

Hiro, D. The longest august: the unflinching rivalry between India and Pakistan. Bold Type Books, 2015. 
Kapur, Anup Chand. "The Nature of Indian Politics.” The Indian Political System.11 $1^{\text {th }}$ ed.,S. Chand \& Company Ltd.,1982.

Milton-Edwards, Bevereley. "Religion and Violence: A History of Entanglement." Islam and Violence in the Modern Era . Palgrave Macmillan,2006, (pp. 19-50).

Minault, Gail. The Khilafat movement: religious symbolism and political mobilization in India. Columbia University Press. 1982.

Moore, Stephen D. God's Gym : Divide Male Bodies of the Bible. Routledge,1996.

Nongbri, Brent. Before Religion.: A History of a Modern Concept. Yale University Press, 2013.

Saler, Benson. Conceptualizing Religion: Immanent Anthropologists, Transcendent Natives, and Unbounded Categories (Vol. 56). Brill.1993

Shape, Eric J. Understanding Religion. St. Martin,1983.

Smith, Jonathan Z. "God Save This Honorable Court: Religion and Civic Discourse.” Relating Religion : Essays in the Study of Religion. University of Chicago Press, 2004. pp 375390.

---. Relating Religion: Essays in the Study of Religion. University of Chicago Press, 2004. p.193. Talbot, Ian, and Gurharpal Singh. Partition and region: Bengal, Punjab and the Partition of the Subcontinent. Oxford University Press, 1999. 